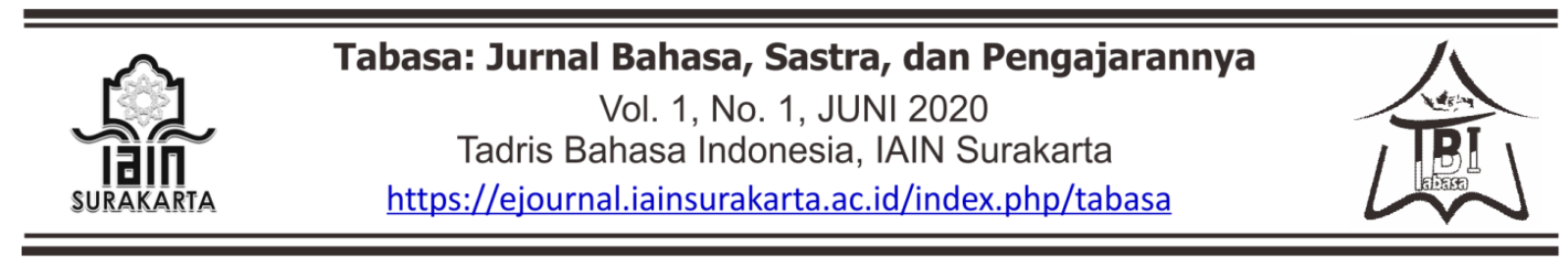

\title{
POLA KARAKTERISTIK RAGAM BAHASA ISTILAH PADA MASA PANDEMI COVID 19 (CORONAVIRUS DISEASE 2019)
}

\author{
Wahyu Oktavia, Nur Hayati \\ MTs Muhammadiyah 05 Kemusu, SMPTQ Abi Ummi Ampel \\ oktaviawahyu17@gmail.com, nurh5898@gmail.com \\ *Diterima: 13 Juli 2020, Disetujui: 06 Agustus 2020
}

\begin{abstract}
The term is a form of words or a combination of words used to express a concept to get a certain meaning. This study aims to describe the characteristic patterns of various language terms during the Covid pandemic 19. This research uses a qualitative descriptive approach where the results of the analysis are described in words but not in numerical form. The subjects in this study used new terms that existed during the Covid pandemic 19. While the object in this study was a characteristic pattern focused on the variety of Covid term languages 19. The technique used was observation and data collection techniques. The results showed that there were 38 data patterns of language characteristics of Covid 19 terms analyzed and then classified into 14 data in English form, 9 data in synonym form, 10 data in abbreviated form and 5 data in acronym form.
\end{abstract}

Keywords: Variety of Languages, Terms, Covid 19

\section{Abstrak}

Istilah merupakan bentuk kata atau gabungan dari sebuah kata yang digunakan untuk mengungkapkan suatu konsep untuk mendapatkan suatu makna tertentu.Penelitian ini bertujuan untuk mendeskripsikan pola karakteristik ragam bahasa istilah pada masa pandemi Covid 19.Penelitian ini menggunakan pendekatan deskriptif kualitatif dimana hasil analisisnya diuraikan dengan kata-kata melainkan bukan dalam bentuk angka.Subjek dalam penelitian ini menggunakan istilah-istilah baru yang ada pada masa pandemi Covid 19.Sedangkan objek dalam penelitian ini adalah pola karakteristik yang difokuskan pada ragam bahasa istilah Covid 19.Teknik yang digunakan yaitu teknik observasi dan penjaringan data. Hasil penelitian menunjukkan bahwa terdapat 38 data pola karakteristik ragam bahasa istilah Covid 19 yang dianalisis dan kemudian diklasifikasikan menjadi 14data dalam bentuk bentuk bahasa Inggris, 9 data dalam bentuk sinonim, 10data dalam bentuk singkatan dan 5 data dalam bentuk akronim.

Kata Kunci: Ragam Bahasa, Istilah, Covid 19

\section{PENDAHULUAN}

Perkembangan bahasa di Indonesia semakin berkembang pesat.Dengan bahasa sekarang telah memberikan andil besar bagi perkembangan peradaban manusia, sehingga manusia dapat menyampaikan dan mengembangkan pemikirannya.Bahasa merupakan suatu yang tidak dapat dipisahkan dari kehidupan manusia karena dengan bahasa, manusia dapat mengungkapkan segala hal yang ada dalam pikirannya (Saharuddin, 2016:69). Bahasa sebagai sarana dalam berkomunikasi dapat bermakna ketika digunakan di dalam kehidupan sehari- 
hari.Dengan begitu bahasa dijadikan cerminan pikiran manusia dan menjadi fondasi penting dalam keberlangsungan hidup (Oktavia, 2019:62).

Bahasa sangat berperan dalam situasi dan kondisi tertentu pada umumnya karena bahasa dapat memfasilitasi komunikasi interpersonal dalam mempelajari dan memaknai sesuatu.Bahasa merupakan suatu bentuk komunikasi terpenting bagi manusia.Bahasa berfungsi sebagai alat komunikasi untuk mendapatkan informasi.Rahardi (2006:45) yang menyatakan bahwa bahasa berfungsi sebagai alat komunikasi yang digunakan untuk menyatakan ekspresi diri dari segala hal yang tersirat di dalam pikiraan maupun perasaannya.Eksistensi bahasa Indonesia yang dianggap sebagai bahasa persatuan selain dipengaruhi oleh kekuatan penggunanya juga dapat didukung oleh kemampuannya dalam mengungkapkan fenomena bahasa baru yang berkembang.Bahasa secara luas yakni berupa suatu pengungkapan seseorang yang berupa simbol-simbol. Oleh karena itu perkembangan bahasa Indonesia juga sangat berhubungan pada tingkat keberhasilan dalam menciptakan sebuah kosakata dan istilah-istilah yang baru.

Setelah ditetapkan sebagai pandemi global oleh Badan Kesehatan Dunia (WHO) selama lebih dari 4 bulan lamanya, wabah virus corona yang terdeteksi pertama di kota Wuhan Cina pada akhir tahun 2019 lalu sampai sekarang masih saja terus menyabar di kalangan masyarakat. Di sela-sela itu terselip kata-kata atau istilah-istilah yang menjadi tren diantara para pengguna bahasa. Kenyataannya saat ini banyak bermunculan dan berdar istilah-istilah terbaru tentang pandemi virus corona (Covid 19) yang telah menyebar di seluruh dunia yang tak terkecuali di Indonesia.

Penggunaan istilah-istilah tersebut digunakan untuk menggambarkan situasi yang sangat berbeda.Akan tetapi jika penggunaan istilah dipahami dan dimaknai secara berbeda maka makna dari istilah tersebut menjadi tidak tepat.Oleh karena itu sangat penting bagi masyarakat bahasa memahami istilah yang sering digunakan untuk menggambarkan perkembangan pandemi virus corona.Covid 19 masih menjadi atensi besar bagi masyarakat publik.Di tengah popularitas Covid 19 ada beberapa istilah yang selalu terdengar tanpa sengaja.

Tak hanya perkembangannya yang selalu berkembang.Istilah-istilah baru pun banyak bermunculan dan berkembang sangat pesat yang tanpa kita sadari.Tidak jarang istilah-istilah yang digunakan dapat dipahami secara berbeda sehingga berpengaruh pada perkembangan bahasa selanjutnya. Perkembangan bahasa Indonesia selama masa pandemi sangat berpengaruh terhadap keberadaan bahasa Indonesia sebagai bahasa persatuan. Hal itu disebabkan karena adanya fenomena bahasa baru yang dianggap membawa kebingungan di sebagian masyarakat.Tidak dapat disangka bahwa selama pandemi Covid 19 merebak di masyarakat, begitu banyak kosakata bermunculan.Dengan berbagai banyaknya istilah-istilah baru yang muncul dalam masa pandemi Covid 19 menjadi acuan untuk dikaji dan diteliti, karena dianggap belum ada penelitian sebelumnya.

Penelitian yang relevan dengan penelitian yang akan dilakukan yakni menurut Hariyanto (2010) dengan judul "Istilah-Istilah Khusus dalam Chatting". Persamaan penelitian ini sama-sama membahas mengenai istilah-istilah.Perbedaannya terletak pada objek yang digunakan. Pada penelitian sebelumnya menggunakan objek yang terfokus pada chatting, sedangkan pada penelitian yang akan dilakukan objek lebih terfokus pada peristiwa pandemi Covid 19. Penelitian yang relevan juga dilakukan oleh Wiratno dkk (2017) dengan judul "Analisis Kualitas Terjemahan Terhadap Istilah-Istilah Teknis di dalam Game Ragnarok Online Karya Gravity".Persamaan penelitian ini sama-sama memiliki subjek mengenai beberapa ragam istilah. 
Sedangkan perbedaanya terlihat pada objek yang digunakan yaitu pada penelitian sebelumnya menggunakan istilah-istilah teknis dalam game Ragnarok, dan pada penelitian yang akan diteliti lebih terfokus pada istilah-istilah dalam masa pandemi Covid 19.

Sehubungan dengan hal tersebutbahasa Indonesia yang merupakan bahasa nasional dan bahasa negara Indonesia yang sudah menjadi ciri khas Bangsa. Namun, sekarang ini bahasa Indonesia telah banyak dipengaruhi oleh beberapa pola-pola karakteristik ragam bahasa yang sangat berbeda. Adapun jenis pola karakteristik ragam bahasa istilah yang difokuskan dalam penelitianini adalah bentuk bahasa Inggris, sinonim, singkatan dan akronim.

\section{KAJIAN LITERATUR}

Adapun teori-teori yang dianggap relevan dalam penelitianpola karakteristik ragam bahasa istilah pada masa pandemi covid 19 yakni mengacu pada tiga teori antara lain;hakikat bahasa, ragam bahasa dan istilah.

\section{Hakikat Bahasa}

Bahasa adalah sebuah lambang berupa bunyi yang memiliki sifat sewenangwenang (arbitrer) dan dipakai oleh beberapa anggota masyarakat untuk melakukan interaksi dalam berkomunikasi. Bahasa bersifat lingua franca dimana bahasa digunakan sebagai penghubung untuk berinteraksi antara dua etnis atau lebih yang masing-masing memiliki bahasa sendiri-sendiri (Chaer, 2013:2). Bahasa juga digunakan sebagai alat komunikasi manusia untuk mengekspresikan pikiran dan perasaannya (Sumarsono, 2017:18).

Sebagaimana yang sudah dijelaskan di atas bahwa bahasa memiliki fungsi penting dalam kehidupan.Sintia (2017:7) menambahkan bahwa bahasa merupakan suatu rangkaian sistem bunyi atau simbol yang diperoleh dari alat ucap manusia, dan bunyi tersebut memiliki makna yang secara umum digunakan oleh sekelompok manusia (penutur) untuk berkomunikasi (melahirkan pikiran dan perasaan) kepada orang lain. Bahasa juga dipandang sebagai alat komunikasi sebagai tingkah laku sosial (social behavior) yang dipakai untuk berkomunikasi.

Bahasa merupakan bentuk komunikasi yang digunakan oleh setiap individu dalam memberikan informasi yang berupa pikiran, gagasan, maksud maupun perasaan (Oktavia, 2018:319).Utamanya fungsi bahasa adalah sebagai sarana komunikasi dan interaksi.Bahasa dalam hal ini berfungsi sebagai alat komunikasi untuk mendapatkan informasi.Kehadiran informasi merupakan sebuah kebutuhan manusia yang sangat diperlukan pada kehidupan modern ini (Hadianto, 2018:317).Lebih lanjut Wijayanti (2018:77) menyatakan bahwa bahasa berfungsi sebagai alat komunikasi, baik yang digunakan secara langsung maupun tidak langsung.Komunikasi langsung merupakan komunikasi dua arah yang menuntut kehadiran orang kedua. Pada sisi lain, komunikasi tidak langsung yaitu komunikasi yang tidak memerlukan kehadiran pembicara karena sudah dilakukan melalui tulisan. Dengan begitu, fungsi bahasa digunakan sebagai alat komunikasi yang salah satunya untuk melahirkan suatu pikiran, sehingga memungkinkan perasaan seseorang untuk bekerja sama dengan orang lain.

Diperkuat dengan pendapat Abdullah (2013:3) bahwa bahasa itu memiliki beberapa fungsi dalam bahasa, antara lain bahasa berfungsi sebagai sistem, lambang, bunyi, bermakna, arbitrer, konvensional, produktif, unik, universal, bervariasi dan berfungsi sebagai identitas suatu kelompok. Bahasa sebagai sistem artinya bahasa terdiri atas unsur-unsur yang disusun secara teratur.Bahasa sebagai lambang sering disebut dengan ilmu semiotika atau semiologi yang berarti ilmu yang

Tabasa: Jurnal Bahasa, Sastra Indonesia, dan Pengajarannya

Vol. 1, No. 1, Juni 2020 
mempelajari tanda-tanda yang ada dalam kehidupan manusia, termasuk bahasa.Bahasa sebagai bunyi dapat diartikan sebagai bunyi atau bahasa lisan.Bahasa sebagai makna yaitu sistem lambang yang berwujud bunyi sebuah lambang tentu melambangkan sesuatu yaitu suatu pengertian, suatu konsep, suatu ide dan pikiran.Bahasa arbitrer berarti tidak ada hubungan wajib antara lambang bahasa (yang berwujud bunyi itu) dengan konsep dan pengertian yang terkadang dalam lambang tersebut.Bahasa konvensional artinya bahasa harus mematuhi konvensi bahwa lambang tertentu digunakan untuk mewakili konsep yang diwakilinya.Bahasa produktif menekankan pada unsur-unsur bahasa yang terbatas, meskipun secara relatif sesuai dengan fungsi sistem yang berlaku.Bahasa harus unik yaitu bahasa yang harus memiliki ciri khas yang spesifik dan tidak dimiliki oleh bahasa yang lain. Bahasa sebagai universal harus memiliki sifat dan ciri masingmasing. Bahasa harus bervariasi yaitu bahasa yang digunakan harus memiliki suatu perbedaan antara bahasa satu dengan bahasa yang lainnya. Bahasa sebagai identitas kelompok adalah bahasa yang memiliki ciri-ciri pembeda yang paling menonjol, karena lewat bahasa setiap kelompok sosial merasa dirinya sebagai kesatuan yang berbeda dari kelompok lain.

Dapat disimpulkan bahwa bahasa adalah alat komunikasi yang bersifat manasuka, yang berfungsi untuk menyampaikan pesan dari pembicara disampaikan dari penutur kepada orang lain dengan maksud dan makna tertentu sebagai alat komunikasi sosial yang saling berhubungan serta bahasa itu dapat disampaikan kepada khalayak umum untuk memperoleh maksud dan tujuan tertentu.

\section{Ragam Bahasa}

Ragam bahasa sering disebut juga dengan variasi bahasa.Menurut Abdullah (2013:173) ragam bahasa merupakan jenis penggunaan bahasa menurut pemakainya yang berbeda-beda. Perbedaan tersebut terlihat pada topik yang dibicarakan, menurut hubungan pembicara, kawan bicara, dan orang yang dibicarakan serta menurut medium pembicaraan.Chaer (2010: 62) menyatakan bahwa ragam bahasa dapat dilihat dari dua pandangan.Pertama, variasi atau ragam bahasa itu dilihat sebagai akibat adanya keragaman sosial penutur bahasa itu dan keragaman fungsi bahasa itu. Kedua, variasi atau ragam bahasa itu sudah ada untuk memenuhi fungsinya sebagai alat interaksi dalam kegiatan masyarakat yang beraneka ragam. Oktavia (2018:318) menyampaikan bahwa ragam bahasa adalah jenis variasi bahasa yang pemakaiannya disesuaikan dengan fungsi dan situasinya, tanpa mengabaikan kaidah-kaidah pokok yang berlaku dalam bahasa yang disampaikan.

Ragam bahasa erat kaitannya dengan ragam fornmal dan nonformal. Ragam formal adalah ragam bahasa yang paling mendasar dan sering dijadikan patokan untuk menentukan baik buruknya sebuah bahasa.Bahasa formal adalah suatu bahasa yang dengan sengaja disusun menurut aturan-aturan konseptual dan logis, khusus dan digunakan untuk memenuhi suatu tujuan khusus secara konsisten, persis, dan lengkap dengan memperhatikan aturan sintaksis, semantis dan logika.Tidak dapat dipungkiri bahwa dalam ragam bahasa bukan hanya bersifat formal saja, namun ada juga ragam bahasa yang bersifat nonformal.Bahasa nonformal merupakan variasi bahasa yang tetap hidup dan terus berkembang sesuai dengan perkembangan zaman.Perkembangan tersebut bisa dilihat dari pelafalan, tata bahasa, dan kosakata.Ragam bahasa nonformal adalah ragam bahasa yang digunakan dalam situasi tidak resmi untuk berbincang-bincang secara santai 
(Sumarsono, 2017:33).Ragam bahasa nonformal dapat dilihat dari adanya ragam bahasa Asing, sinonim, singkatan dan akronim.

Bahasa Inggris atau bahasa asing merupakan bahasa internasional.Selama ini paling tidak sebelum adanya buku pedoman umum pembentukan istilah, pengambilan kosakata asing baik sebagai kata maupun istilah, dilakukan secara alami tanpa patokan tertentu (Santoso, 2012:98).Bahasa asing yang sering dijumpai dalam bahasa iklan adalah bahasa Inggris.Bahasa Inggris merupakan bahasa yang paling umum yang digunakan di seluruh dunia.

Sinonim merupakan hubungan semantik antara beberapa kata yang memiliki kesamaan makna menurut tujuan pemakaiannya. Selain itu Utami (2010:19) mengatakan bahwa sinonim merupakan kajian semantik persamaan kata yang memungkinkan terbentuk kelompok pasangan sinonim. Sehingga kelompok kata yang memiliki persamaan akan mengikuti kelompok pasangan sinonim. Akan tetapi tidak mutlak kata bersinonim memiliki kesamaan dari makna (Adelin, 2013:3). Sehingga dapat diartikan apabila terdapat kata-kata atau ungkapan yang memiliki perbedaan secara fonemis, makna yang dimunculkan juga akan berbeda terletak pada nuansanya.

Singkatan adalah sebuah huruf atau sekumpulan huruf sebagai bentuk kependekan dari sebuah kata atau beberapa kata. Oktavia (2018:320) menyatakan bahwa singkatan juga sering digunakan dalam beberapa ragam lisan dan tulisan.Dalam penulisan singkatan harus sesuai dengan bentuk penulisan yang sesuai dengan PUEBI (Pedoman Umum Ejaan Bahasa Indonesia).Lebih luas Arisanti (2018:107) singkatan merupakan kata atau gabungan kata yang penulisan dan ucapannya disingkat. Singkatan ialah suatu bentuk istilah yang tulisannya dipendekkan menurut tiga cara yaitu singkatan gabungan huruf, singkatan gabungan huruf dan angka. Muslich (2009:168) mengatakan bahwa singkatan gabungan huruf merupakan pemendekan atau penyingkatan kata dari suatu gabungan huruf tertentu, sedangkan singkatan huruf dan angka adalah singkatan yang terdiri dari huruf dan angka.

Akronim adalah gabungan dari suatu kependekan kata dari huruf atau suku kata maupun bagian lain yang ditulis dan dilafalkan sebagai kata yang wajar. Selain itu akronim juga bisa diartikan sebagai singkatan yang tersusun dari dua kata atau lebih yang diperlakukan sebagai sebuah kata.Akronim biasanya dibuat dengan mengindahkan keserasian kata dari berbagai susunan bunyi vokal dan konsonan yang sesuai dengan pola kata bahasa Indonesia yang lazim serta mudah untuk diingat (Oktavia, 2018:136).Proses akronimisasi akan menghasilkan bentuk kata yang disebut akronim. Dalam proses pembentukannya sebuah makna atau konsep yang ditampilkan dalam bentuk dua buah kata atau lebih, disingkat kata-katanya sehingga membentuk sebuah kata baru(Pateda, 2001:150).Istilah akronim dapat dilihat dari dua cara yaitu akronim gabungan suku kata dan akronim campuran. Akronim gabungan suku kata adalah gabungan dari beberapa unsur nama diri, yang berupa suku kata dan huruf yang ditulis dengan huruf awal kapital. Akronim campuran adalah akronim yang merupakan gabungan huruf, suku kata atau keduanya dari deret kata dan ditulis dengan huruf kecil (Muslich, 2009:168).

\section{Istilah}

Istilah merupakan suatu kata atau bisa diartikan sebuah gabungan kata yang berfungsi sebagai pengungkap sebuah mana, proses, konsep, atau sifat yang menjadi ciri khas disuatu bidang tertentu. Secara terminologi istilah adalah sebuah kata atau frasa yang digunakan sebagai nama atau lambang yang mengungkapkan

Tabasa: Jurnal Bahasa, Sastra Indonesia, dan Pengajarannya

Vol. 1, No. 1, Juni 2020 
sebuah mana dari istilah kata tersebut. Istilah sering disebut juga dengan kosa kata yang merupakan keseluruhan kata yang berada dalam ingatan seseorang dan akan menimbulkan reaksi setelah dibaca dan didengar (Wiratno, 2017:37).

Diperluas oleh Hariyanto (2010:296) bahwa istilah atau kosa kata merupakan seluruh kata yang sudah didengar yang dimiliki oleh seorang pembicara yang telah disusun seperti kamus dan disertai dengan penjelasan yang singkat dan lengkap agar mudah dimengerti oleh pembaca.Kata secara sederhana merupakan satuan terkecil yang dapat berdiri sendiri dan memiliki arti kata. Kosakata merupakan himpunan kata yang dimiliki oleh seseorang atau etnis lain dan merupakan bagian dari suatu bahasa tertentu (Waridah, 2010:22). Berbeda dengan Susanti (2016:229) menambahkan bahwa kosakata digunakan untuk menghimpun semua kata-kata yang dimengerti oleh seseorang atau kata-kata yang kemungkinan akan digunakan oleh seseorang untuk menyusun kalimat baru.

\section{METODE PENELITIAN}

Penelitian ini menggunakan pendekatan deskriptif kualitatif yaitu prosedur penyelesaian masalah dengan memaparkan keadaan objek penelitian berdasarkan fakta-fakta yang tampil sebagaimana adanya (Sugiyono, 2014:205).Sumber data penelitian kualitatif adalah tampilan kata-kata lisan atau tertulis yang dicermati oleh peneliti dan benda-benda yang diamati sampai detailnya agar dapat ditangkap makna yang tersirat dalam dokumen atau bendanya.Data yang diperoleh tidak berbentuk bilangan atau angka statistik, tetapi dalam bentuk kualitatif yang dinyatakan dalam kata-kata.Penulis melakukan analisis isi dengan memberikan pemaparan yang diteliti dalam bentuk uraian (Arikunto, 2010:22).Subjek dalam penelitian ini adalah istilah mengenai virus Covid 19.Sedangkan objek dalam penelitian ini adalah pola karakteristik yang difokuskan pada ragam bahasa pada istilah-istilah mengenai Covid 19.Teknik yang digunakan dala penelitian ini adalah teknik observasi dan penjaringan data.Teknik observasi dilakukan secara langsung tanpa perantara apapun dalam melakukan suatu pemerolehan data. Pada pemerolehan data dilakukan dengan cara penjaringan dokumen dari data-data yang sudah terkumpul berdasarkan sumber-sumber data berupa data-data tertulis, foto, gambar, kata-kata mengenai ragam bahasa istilah pada masa pandemic Covid 19 sebagai bahan untuk dijadikan analisis penelitian.

\section{HASIL DAN PEMBAHASAN}

Pola karakteristik ragam bahasa istilah pada masa pandemi Covid 19, dapat dianalisis dengan berbagai jenis ragam bahasa, antara lain dengan menggunakan ragam bahasa dalam bahasa Inggris (asing), sinonim (persamaan kata), singkatan yang terbagi dalam bentuk bahasa Indonesia dan bahasa Inggris serta akronim (pemendekan kata).

\section{Bahasa Inggris}

Dalam penelitian ini penggunaan istilah bahasa Inggris lebih dominan ditemukan, karena pemakaian kosa dalam bentuk bahasa Inggris tersebut dirasa lebih memiliki nilai tinggi dan praktis dibandingkan dengan menggunakan bahasa Indonesia sendiri. Pemakaian kosa kata bahasa Inggris pada iklan ini juga bertujuan untuk menunjukkan kesan yang modern, sehingga istilah tersebut diharapkan mampu memunculkankebaruan istilah bahasa.Temuan data dalam bentuk istilah bahasa Inggris diantaranya sebagai berikut;

Tabel 1 Bentuk Istilah Bahasa Inggris

\begin{tabular}{|l|l|r}
\hline No & Bahasa Inggris & Makna \\
\hline
\end{tabular}




\begin{tabular}{|c|l|l|}
\hline 1. & New normal & Normal baru \\
\hline 2. & Social distancing & Jaga jarak \\
\hline 3. & Physical distancing & Pembatasan fisik \\
\hline 4. & Lockdown & Penutupan \\
\hline 5. & Swab test & Tes usab \\
\hline 6. & Rapid test & Tes cepat \\
\hline 7. & Suspect & Terduga \\
\hline 8. & Handsinitizer & Pensanitasi tangan \\
\hline 9. & Local transmission & Penularan lokal \\
\hline 10. & Imported case & Kasus impor \\
\hline 11. & Thermo gun & Pistol termometer \\
\hline 12. & Panic buying & Beli panik \\
\hline 13. & Herdy immunity & Kekebalan kelompok \\
\hline 14. & Flattening the curve & Pelandaian kurva \\
\hline
\end{tabular}

Data (1) kata new normal dapat diartikan sebagai kenormalan baru yang belum pernah ada sebelumnya, dimana pada masa pandemiknew normal adalah perubahan budaya misalnya dengan selalu menerapkan Pola Hidup Bersih dan Sehat (PHBS), keadaan pada masa Covid 19 mengharuskan masyarakat beradaptasi dengan kenormalan baru seperti memakai masker ketika keluar rumah, selalu mencuci tangan dan menjaga jarak fisik ketika berada di tempat yang ramai. Data (2) social distancing merupakan salah satu langkah pencegahan dan pengendalian infeksi virus corona dengan menganjurkan orang sehat untuk membatasi kunjungan ke tempat ramai dan kontak langsung dengan orang lain. Ketika menerapkan social distancing, seseorang tidak diperkenankan untuk berjabat tangan serta harus menjaga jarak setidaknya 1 meter saat berinteraksi dengan orang lain, terutama dengan orang yang sedang sakit atau berisiko tinggi menderita Covid19.

Data (3) physical distancing dapat diartikan sebagai pembatasan fisik.Pemerintah meminta agar masyarakat tetap melakukan interaksi sosial seperti biasa. Namun untuk saat ini dapat dilakukan dengan cara lain yang tidak memerlukan kehadiran fisik secara langsung, semisal memanfaatkan teknologi informasi dan menggunakan media sosial. Data (4) lockdown (penutupan) merupakan situasi yang melarang warga untuk masuk ke suatu tempat karena kondisi darurat.Lockdown juga bisa berarti negara yang menutup perbatasannya, agar tidak ada orang yang masuk atau keluar dari desa, kota bahkan negaranya.

Data (5) swab test dapat diartikan sebagai metode dalam pengambilan sampel serta merupakan tindak lanjut dari rapid test. Swab test ini biasanya digunakan setelah 10 hari ODP ataupun PDP melakukan rapid dan telah melakukan karantina baik mandiri ataupun tidak. Seseorang dinyatakan PDP atau ODP merupakan seseorang yang menunjukkan ada reaksi dari virus kedalam tubuh. Swab test dijalankan dengan prosedur pengambilan sampel berupa cairan dari seorang ODP ataupun PDP melalui tenggorokan atau pangkal hidung.Data (6) rapid testmerupakan cara pertama yang dilakukan guna mengetahui reaktif atau tidaknya antibody manusia terhadap virus. Pengambilan sampel pada rapid test dengan mengambil darah baik dari ujung jari maupun pada pembuluh darah bagian dalam siku tangan manusia. Rapid test diwajibkan bagi pendatang dari luar daerah terlebih dari red zone.

Data (7) suspectmerupakan istilah lain dari pasien dalam pengawasan. Seseorang dinyatakan menjadi pasien dalam pengawasan apabila menunjukkan gejala reaktif pada kegiatan surveilans. Keadaan seseorang yang menjadikan reaktif

Tabasa: Jurnal Bahasa, Sastra Indonesia, dan Pengajarannya

Vol. 1, No. 1, Juni 2020 
setelah melaukan swab test. Pasien dalam pengawasan dengan gejala ringan dapat melakukan karantina di rumah sakit manapun. Sedangkan suspect dengangejala berat akan melaukan isolasi mandiri di rumah sakit rujukan. Data (8) handsinitizer merupakan cairan pembersih tangan yang tidak memerlukan air untuk membilasnya. Handsinitizer merupakan komponen campuran dari beberapa senyawa kimia yang difungsikan untuk antiseptik pembunuh kuman.Senyawa gabungan dalam handsinitizer merupakan cairan berbasis alkohol yang bersifat panas sehingga mampu membunuh virus.

Data (9) local transmission merupakan istilah asing yang berarti penularan atau penyebaran penyakit yang terjadi secara lokal.Lokal berarti tempat penularan itu terjadi hanya dalam suatu lokasi dimana tempat pasien positif Covid 19 berada.Penularan secara lokal yakni pasien tertular dari orang yang sebelumnya terjangkit virus di daerah tempat mereka tinggal sebelumnya. Data (10) imported case atau yang sering diartikan sebagai kasus impor yaitu dimana orang yang diduga terjangkit virus Covid 19 yang berasal dari luar negeri yang kemungkinan tertular secara langsung saat berada di luar negeri.

Data (11) thermo gun merupakan alat bantu untuk mendeteksi suhu atau mengukur suhu tubuh seseorang tanpa menyentuh obyek tubuh yang memiliki bentuk menyerupai pistol. Termometer ini digunakan karena memiliki radiasi inframerah yang dapat mengukur suhu tubuh dengan cepat, tepat dan akurat. Data (12) panic buying berarti beli panik dengan maksud situasi ketika seseorang atau suatu kelompok membeli suatu produk dalam jumlah besar karena khawatir persediaan barang di suatu toko akan cepat habis. Dengan adanya rasa khawatir itu mendorong munculnya tindakan antisipatif atau mengantisipasi bencana atau kenaikan harga pada setiap persediaan barang.

Data (13) herdy immunity yang berarti kekebalan kelompok.Kekebalan terhadap suatu penyakit bisa dilakukan dengan pemberian vaksin secara meluas pada sebagian orang dalam sebuah kelompok setelah mereka terpapar dan sudah sembuh dari virus Covid 19. Data (14) flattening the curve merupakan istilah asing yang berarti pelandaian kurva. Upaya untuk memperlambat penyakit menular dalam virus Covid 19 dapat dilihat melalui pelandaian kurva. Kurva menggambarkan tentang bagaimana situasi atau kondisi, jumlah penderita yang atau prediksi pada setiap kasus yang terinfeksi virus Covid 19 berlangsung.

\section{Sinonim}

Ragam bahasa istilah sinonim yakni bentuk dari suatu istilah yang dianggap memiliki makna sama dengan istilah-istilah yang ditemukan. Adapun ragam bahasa bentuk istilah yang ditemukan antara lainsebagai berikut;

Tabel 2 Bentuk Istilah Sinonim

\begin{tabular}{|l|l|l|}
\hline No & \multicolumn{1}{|c|}{ Sinonim } & \multicolumn{1}{c|}{ Makna } \\
\hline 15. & Isolasi & Mandiri \\
\hline 16. & Disinfektan & Pemusnah bakteri \\
\hline 17. & Karantina & Penahanan \\
\hline 18. & Positif & Terjangkit \\
\hline 19. & Wabah & Peningkatan \\
\hline 20. & Pandemi & Penyebaran penyakit \\
\hline 21. & Antiseptik & Cairan \\
\hline 22. & Protokol & Aturan main \\
\hline 23. & Klaster & Kelompok \\
\hline
\end{tabular}


Data (15) isolasi memiliki makna yang sama dengan kata mandiri yaitu suatu bentuk pemisahan diri dari orang yang terjangkit oleh virus. Isolasi sering juga dikaitkan dengan kata isolir yang merupakan bentuk kata dari hasil pengaruh belanda.Isolasi juga diartikan sebagai tindakan pemisahan pasien berpenyakit menular dari orang lainnya. Istilah isolasi biasanya digunakan untuk seseorang yang telah menunjukkan gejala terinfeksi virus corona dan berpeluang untuk menginfeksi orang lain, sehingga perlu dipisahkan agar virus tidak menyebar. Data (16) disinfektan yaitu istilah lain dari pemusnahan bakteri. Pemusnahan bakteri pada kasus yang dipaparkan penulis mengenai virus berupa cairan. Cairan yang dibuat berdasarkan takaran tertentu dan berbasis alkohol yang memiliki sifat panas. Disinfektan yang dimaksud adalah cairan yang disemprotkan pada benda mati ataupun bagian-bagian rumah yang dianggap memiliki potensi penularan virus karena sering menjadi tempat untuk berinteraksi banyak orang.

Data (17) karantina yani suatu tempat penampungan yang lokasinya terpencil guna mencegah terjadinya penularan suatu penyakit. Karantina dalam penelitian ini dimaksudkan yaitu upaya pencegahan dan minimalisasi akses keluar masuk pada suatu kelompok atau suatu individu tertentu. Karantina sendiri dapat dibagi menjadi beberapa jenis seperti karantina wilayah yakni pembatasan suatu kelompok utnuk tetap berada di wilayah yang mereka tempati.Karantina mandiri dilakukan oleh individu untuk tidak keluar dari tempat yang ia tinggali, setelah individu tersebut melakukan perjalanan jauh dan dinyatakan negatif setelah melakukan tes.

Data (18) positif yaitu pernyataan dimana suatu hal dinyatakan menghasilkan sesuatu yang baru, mendeteksi adanya hal baru pada tubuh seseorang. Positif terpapar virus, hal tersebut menunjukkan bahwa dalam tubuh seseorang dinyatakan terdapat virus yang memasukinya. Proses dalam adanya virus secara positif atau tidak harus dilakukan beberapa kali tes. Apabila dalam antibody manusia dinyatakan reaktif terhadap virus, maka orang tersebut dinyatakan positif dalam tubuhnya terjangkit Covid19. Data (19) wabah yakni sebuah kata yang diambil dari bahasa Arab yang berarti suatu penyakit yang menular serta proses terjangkitnya sangat cepat yang menyerang sejumlah orang dengan sangat cepat. Wabah dapat diartikan sebagai penyakit menular yang berjangkit dengan cepat serta menyerang sejumlah orang disuatu tempat yang luas.Berdasarkan istilah penelitian ini dapat dikatakan wabah karena penularan Covid-19 sangat rentang sehingga jumlah penderita selalu melonjak meskipun upaya kesehatan sudah dilakukan. Selain itu, wabah Covid19 tidak hanya menyerang satu wilayah, akan tetapi penyebarannya semakin luas sehingga seluruh wilayah terjangkit virus Covid19.

Data (20) pandemik yakni sebutan untuk penyakit menular yang dapat mengancam kalangan banyak orang yang ada didunia secara bersamaan dalam satu waktu. Penggunaan istilah pandemik hampir sama dengan wabah yakni penyebaran virus yang terjadi secara luas dan merata. Akan tetapi pandemik bersifat internasional yakni penggunaan istilah yang diperuntukkan untuk negara yang satu dengan yang lain karena satu masalah kesehatan yang sama. Sedangkan untuk wabah lebih lokal yakni penggunaan istilah yang diperuntukkan untuk negara yang satu dengan yang lain karena satu masalah kesehatan yang sama. Sedangkan untuk wabah lebih lokal yakni penggunaan istilah jenis penyakit padasatu wilayah saja. Data (21) antiseptik yaitu cairan kimia yang terdapat pada jaringan hidup sebagai penahan atau penghancur pertumbuhan jasad renik. Cairan ini menjadi obat luar utama yang digunakan dalam pencegahan penularan virus sebelum vaksin virus yang sesungguhnya belum ditemukan, antiseptik bersifat bersih dan membersihkan

Tabasa: Jurnal Bahasa, Sastra Indonesia, dan Pengajarannya

Vol. 1, No. 1, Juni 2020 
sehingga cairan ini digunakan sebagai pencegahan.Umumnya virus akan menjangkit seseorang yang pada tubuhnya tidak diberi antiseptik.

Data (22) protokol, merupakan surat resmi yang memuat hasil perundingan ataupun persetujuan ataupun aturan yang mengatur dalam lingkup komunikasi dua atau lebih syarat. Penggunaan istilah protokol disesuaikan dengan kebutuhan dan keadaan mengingat hakikat protokol adalah sama yakni sebagai syarat dan peraturan. Maraknya penyebaran virus berdampak pada seluruh tatana kehidupan. Pembolehan seseorang dalam melakukan aktivitas ditengah maraknya pandemik harus mengikuti protokol yang ada. Protokol kesehatan ditengah pandemik ini digunakan sebagai syarat dan sebagai aturan yang mesti diindahkan semua kalangan guna meminimalisir tingkat penularan virus yang lebih banyak. Data (23) klaster adalah suatu bentuk sistem yang berfungsi sebagai pengklasifikasian dari mana asal penyebaran virus itu terjadi.Penyebaran virus yang begitu luas pada seluruh jangkauan daerah memerlukan proses identifikasi klaster pada setiap pasien.Klaster dimaksudkan untuk mendata daerah yang memiliki resiko penyebaran tertinggi. Identifikasi klater pada penyebaran virus memudahkan untuk memberikan peraturan tatanan kehidupan sebagai upaya minimalisasi penyebaran yang lebih luas.

\section{Singkatan}

Ragam bahasa singkatan dalam penelitian istilah-istilah Covid 19 dapat diklasifikasi menjadi dua bentuk, yaitu singkatan dalam bentuk bahasa Inggris dan bahasa Indonesia.Singkatan merupakan kata yang tersusun dari gabungan huruf yakni dengan memendekkan atau menyingkat kata dari suatu gabungan huruf tertentu.Adapun bentuk data singkatan yang diperoleh antara lain;

Table 3 Bentuk Istilah Singkatan Bahasa Inggris

\begin{tabular}{|l|l|l|}
\hline No & \multicolumn{1}{|c|}{ Singkatan } & \multicolumn{1}{c|}{ Kepanjangan } \\
\hline 24. & WFH & Work From Home \\
\hline 25. & SFH & Study From Home \\
\hline 26. & PCR & Polymerase Chain Reaction \\
\hline
\end{tabular}

Data (24) WFH merupakan kepanjangan dari Work From Home yang berarti bekerja dari rumah. Istilah WFH merupakan singkatan dari bahasa Inggris tetapi sifatnya kian menjadi lokal menurut tatanan singkatan. Pemberlakuan WFH pada masa pandemik guna mencegah penularan yang berlebih. Pada dasarnya bekerja merupakan aktivitas yang dilakukan orang lain yang sebagian besar memerlukan jarak tempuh. Hal tersebut mendasari pertimbangan penyebaran virus setiap perjalanan atau sebagai pelaku perjalanan. WFH dilakukan sebagai tindak lanjut dari karantina wilayah. Setiap karyawan diminta untuk menyelesaikan kewajiban atas beban kerja dari rumah masing-masing dengan prosedur kerja dari setiap perusahaan masing-masing.

Data (25) SFH yang merupakan kepanjangandari Study From Home yaitu belajar dari rumah. WFH dan SFH merupakan beberapa cara yang digunakaan untuk menekan angka penularan virus. Sistem protokol kesehatan pada SFH secara garis besar sama dengan WFH. SFH mewajibkan seluruh peserta didik untuk belajar dari rumah masing-masing. Hal ini dilakukan karena rentang penularan virus ke anak memiliki resiko yang berlebihan. Tatanan pendididkan berubah secara keseluruhan. SFH menuntut peserta didik untuk dapat belajar tanpa harus bertatap muka dengan guru dan berada di rumah. Proses belajar tetap berjalan dengan semestinya akan tetapi metode dan model yang digunakan berbeda. Perubahan pembelajaran tatap muka menjadi daring secara keseluruhan.Data (26) PCR atau Polymerase Chain 
Reactionmerupakan pemeriksaan laboratorium untuk mendeteksi keberadaan suatu virus dalam tubuh manusia. Istilah PCR pada masa pandemik viruscorona atau Covid19 digunakan untuk mendeteksi material genetik pada setiap sel yang berupa DNA ataupun RNA. PCR dalam persebaran virus merupakan tindak lanjut dari swab test.

Tabel 4 Bentuklstilah Singkatan Bahasa Indonesia

\begin{tabular}{|l|l|l|}
\hline No & \multicolumn{1}{|c|}{ Singkatan } & \multicolumn{1}{c|}{ Kepanjangan } \\
\hline 27. & ODP & Orang Dalam Pantauan \\
\hline 28. & PDP & Pasien Dalam Pengawasan \\
\hline 29. & ODR & Orang Dalam Risiko \\
\hline 30. & OTG & Orang Tanpa Gejala \\
\hline 31. & KLB & Kejadian Luar Biasa \\
\hline 32. & PSBB & Pembatasan Sosial Berskala Besar \\
\hline 33. & APD & Alat Pelindung Diri \\
\hline
\end{tabular}

Data (27) ODP adalah Orang Dalam Pemantauan. Orang dalam pemantauan tidak berarti seseorang yang telah terjangkit ataupun positif terpapar virus. Orang dalam pantauan tidak memiliki gejala sakit dan tanda-tanda adanya paparan virus, akan tetapi orang itu menjadi seseorang yang dipantau karena telah melakukan kontak fisik dengan pasien yang terjangkit virus. Selain kontak fisik langsung kedatangan orang lain dari daerah yang memiliki potensi penularan tinggi akan berstatus orang dalam pantauan. Data (28) PDP memiliki kepanjangan dari Pasien Dalam Pengawasan yakni dimana seseorang yang dirawat di ruang isolasi rumah sakit yang sebelumnya sudah menjalani proses cek di laboratorium yang hasilnya akan dilaporkan kepada badan penelitian dan pengembangan kesehatan. Berstatus pasien dikarenakan memiliki gejala yang sama dengan penderita Covid19. Berdasarkan hal tersebut seseorang yang memiliki gejala seperti penderita covid, dan melakukan tes, tidak berarti positif terjangkit virus corona.

Data (29) ODR merupakan singkatan dari Orang Dalam Risiko. Keadaan dimana risiko terberat berada disisi terdekat seorang indvidu. Seseorang yang memeiliki risisko tinggi belum tentu ia tertular secara mudah, akan tetapi dampalk terpapar sangat besar. Tempat tinggal, tempat kerja ataupun wilayah yang memiliki tingkat penyebaran luas mendasari risiko-risiko penularan. Data (30) OTG adalah kepanjangan dariOrang Tanpa Gejala atau bisa diartikan sebagai seseorang yang tidak memiliki gejala, namun pernah memiliki kontak langsung dengan orang yang memiliki kasus positif Covid 19. Orang tanpa gejala memiliki tingkat penularan yang cukup tinggi kepada orang lain. Tanpa gejala, individu yang tidak memiliki riwayat sakit dan tidak sedang sakit namun sebenarnya terjangkit virus. Dikarenakan sistem kekebalan tubuh yang ia miliki baik, sehingga secara mandiri virus itu mati. Akan tetapi tidak menutup kemungkinan bahwa OTG mampu menularkan virusnya kepada orang lain.

Data (31) KLB merupakan kepanjangan dari Kejadian Luar Biasa adalah status yang ditetapkan pada suatu daerah yang diyakini telah terpapar suatu penyakit dengan situasi mulai mengkhawatirkan.Selain itu KLB dapat diartikan sebagai timbulnya atau meningkatnya kejadian kesakitan dan kematian yang bermakna secara epidemiologi pada suatu daerah dalam kurun waktu tertentu, dan merupakan keadaan yang dapat menjurus pada terjadinya wabah. Peningkatan status menjadi kejadian luar biasa bukan hanya timbulnya penyakit pada wilayah tertentu dengan angka cukup signifikan. Peristiwa langka yang tengah muncul dan mengharuskan sistem tatanan kehidupan yang baru.

Tabasa: Jurnal Bahasa, Sastra Indonesia, dan Pengajarannya

Vol. 1, No. 1, Juni 2020 
Data (32) PSBB adalah kepanjangan dari Pembatasan Sosial Berskala Besar. Pada dasarnya manusia merupakan makhluk sosial yang tidak dapat menjalankan hidupnya sendiri dan saling bergantung satu sama lain. Kegiatan sosial mengharuskan seseorang untuk kontak fisik dan berkerumun. Pada suatu keadaan tertentu kegiatan sosial ditekan untuk meminimalisir risiko yang lebih tinggi. Sehingga setiap individu dituntut untuk mandiri dalam menjalankan kehidupannya, tidak berkerumun dan menjaga jarak aman antar orang disekitar. Data (33) APD memiliki kepanjangan dari Alat Pelindung Diri yang digunakan oleh petugas medis dalam menangani pasien Covid 19 agar tidak tertular virus.alat pelindung diri ini terdiri dari masker, baju hamzat, dan sarung tangan.

\section{Akronim}

Penggunaan bentuk akronim pada sebuah istilah digunakan untuk mempermudah penulisan yang kata-katanya nanti diharapkan terus diingat oleh seseorang, adapun bentuk ragam bahasa akronim dapat dilihat dari data istilah berikut;

Tabel 5 Bentuk Istilah Akronim

\begin{tabular}{|l|l|l|}
\hline No & \multicolumn{1}{|c|}{ Akronim } & \multicolumn{1}{c|}{ Kepanjangan } \\
\hline 34. & Webinar & Web seminar \\
\hline 35. & Covid 19 & Coronavirus disease2019 \\
\hline 36. & SARS-Cov-2 & Severe Acute Respiratory Syndrome Coronavirus 2 \\
\hline 37. & Masker N95 & Masker Not resistant to oil95 \\
\hline 38 & Fasyankes & Fasilitas pelayanan kesehatan \\
\hline
\end{tabular}

Data (34) webinar merupakan akronim yang memiliki kepanjangan dari Web seminar. Pemberlakuan tatanan kehidupan secara keseluruhan berdampak pada tatanan aktifitas setiap individu. Web seminar, tuntutan untuk selalu melakukan seminar dan melakukan penelitian yang mengharuskan semua tetap berjalan semestinya. Web seminar digunakan sebagai aternatif pengadaan seminar melalui website. Kegiatan penelitian dan seminar tetap berjalan dan tetap dihadiri oleh banyak orang secara virtual.Data (35) Covid 19 memiliki kepanjangan dari Coronavirus disease2019. Sebutan Covid19 untuk memudahkan masyarakat luas untuk mengucapkan dan memaknai secara cepat. Sehingga masyarakat melakukan penyebaran informasi dengan tidak menggunakan bahasa medis. Virus ini merupakan jenis virus yang menyerang anggota pernapasan manusia.

Data (36) SARS-Cov-2yang memiliki kepanjangan dari Severe Acute Respiratory Syndrome Coronavirus 2merupakan jenis akronim gabungan antara huruf dan angka. SARS-Cov-2 lebih dikenal dengan nama virus corona yang merupakan jenis virus baru yang menular ke manusia dan infeksi pada saluran pernapasan. Data (37)Masker N95juga merupakan jenis akronim gabungan dari huruf dan angka yang memiliki kepanjangan masker not resistant to oil 95. Masker respirator ini dugunakan untuk menyaring udara dari partikel yang sangat kecil. Kata "N" yang berarti masker yang tidak tahan minyak.Selain itu angka 95 ini adalah kode seberapa besar kemampuan material yang ada di dalam masker dapat berfungsi dengan baik dalam menyaring partikel.Data (38) fasyankes merupakan akronim gabungan kata yang memiliki kepanjangan fasilitas pelayanan kesehatan.Selain itu fasyankes adalah suatu alat dan tempat yang digunakan oleh sekelompok masyarakat untuk menyelenggarakan suatu kegiatan yang berbasis upaya penyelenggaraan kesehatan. 


\section{PENUTUP}

Bahasa merupakan alat komunikasi yang bersifat manasuka yang disampaikan oleh seseorang kepada orang lain dengan adanya maksud dan makna tertentu yang berfungsi utamanya sebagai alat komunikasi sosial yang saling berhubungan serta bahasa itu dapat disampaikan kepada khalayak umum untuk memperoleh maksud dan tujuan tertentu. Bahasa tidak bersifat statis karena bahasa akan terus berkembang sesuai dengan keadaan dan situasi tertentu. Sehingga memungkinkan bahasa memiliki keragaman. Ragam bahasa merupakan hal yang paling mendasar dan sering dijadikan patokan untuk menentukan baik buruknya sebuah bahasa.Pola karakteristik ragam bahasa istilah dapat dilihat dari berbagai bentuk.Adapun dalam penelitian di atas dapat dilihat dalam bentuk bahasa Inggris, sinonim, singkatan dan akronim. Setiap istilah dan bahasa yang mucul berdasarkan kejadian tertentu dapat dikelompokkan baik menurut asal bahasa, persamaan makna dan bentuk kata.

\section{DAFTAR PUSTAKA}

Abdullah, A., \& Achmad.(2013). Linguistik Umum. Jakarta: Erlangga

Adelin. (2014). Sinonimi.Universitas Indraprasta PGRI: Pascasarjana.

Arikunto, S. (2010). Prosedur Penelitian. Jakarta: Rineka Cipta.

Arisanti, Y. L. (2018). Penggunaan Akronim dan Singkatan dalam Media Sosial Facebook Di Kalangan Remaja SMA Plus Multazam. Jurnal Literasi, 2(2), 104-112.

Chaer, A. (2010). Kesantunan Berbahasa. Jakarta: Rineka Cipta.

Chaer, A. (2013). Pembinaan Bahasa Indonesia. Jakarta: Rineka Cipta.

Hadianto, D. \& Isah C. (2018). Rekonstruksionisme: Metode Komunikatif dalam

Pemerolehan dan Pembelajaran Bahasa untuk Mengembangkan Kemampuan Berbahasa. Jurnal Kata, 2(1), 18-123.

Hariyanto, B. (2010). Istilah-Istilah dalam Chatting (Sebuah Analisis Sosiopragmatik). Jurnal Adabiyyat, 9(2), 294-326.

Muslich, M. (2009).Tata Bentuk Bahasa Indonesia Kajian ke Arah Tata Bahasa Deskriptif. Jakarta: Bumi Aksara.

Oktavia, W. \& Faris, M. (2019).Variasi Bahasa Jargon Dakwah Komunitas Mahasiswa Ukmi (Unit Kegiatan Mahasiswa Islam) Nurul IImi.Jurnal Imajeri, $1(2), 62-69$.

Oktavia, W. (2018).Variasi Jargon Chatting Whatsapp Grup Mahasiswa Tadris Bahasa Indonesia. Jurnal Kata, 2(2), 317-325.

Oktavia, W. (2019).Semantik Ragam Makna pada Judul Film Azab di Indosiar.Jurnal Caraka, 5(2), 133-140.

Pateda, M. (2001).Semantik Leksikal. Jakarta: Rineka Cipta.

Rahardi, K. (2006). Dimensi-Dimensi Kebahasaan. Yogyakarta: Erlangga.

Saharuddin.(2016). Interferensi Bahasa Bugis terhadap Penggunaan Bahasa Indonesia di Pasar Tradisional Desa Sioyong Kabupaten Donggala.e-Jurnal Bahasantodea, 4(1), 68-78.

Santoso, I. (2012). Pendidikan Karakter dan Pembelajaran Bahasa Asing Berwawasan Interkultural.Jurnal Pendidikan Karakter, 2(1), 96-106. 
Sintia, R., D. (2017). Bahasa Iklan Layanan Masyarakat dan Implikasinya Terhadap Pembelajaran Bahasa Indonesia di SMA.Skripsi. Lampung: Program Sarjana. PBSI Universitas Lampung.

Sugiyono. (2014). Metode Penelitian Kuantitatif, Kualitatif dan R\&D. Bandung: Alfabeta.

Sumarsono. (2017). Sosiolinguistik . Yogyakarta: Pustaka Pelajar.

Susanti, Elvi. (2016). Glosarium Kosakata Bahasa indonesia dalam Ragam Media Sosial. Jurnal Dialektika, 3(2), 229-250.

Utami, R. (2010). Kajian Sinonim Nomina dalam Bahasa Indonesia.Thesis. Universitas Sebelas Maret: Pascasarjana.

Waridah, Ernawati. (2010). EYD \& Seputar kebahasa-Indonesiaan. Jakarta: Kawan.

Wijayanti, D. R. (2014).Analisis Kesalahan Berbahasa Bidang Morfologi pada Karangan Narasi Siswa Kelas VII Madrasah Tsanawiyah Muhammadiyah 1 Weleri Tahun Ajaran 2013/2014.Skripsi.Pendidikan Bahasa dan Sastra Indonesia.Universitas Muhammadiyah Surakarta.

Wiratno, T., Dhanu A. P. \& Djatmika.(2017). Analisis Kualitas Terjemahan terhadap Istilah-Istilah Teknis di Dalam Game Ragnarok Online Karya Gravity.Jurnal Prasasti, 2(1), 36-48. 
15| Pola Karakteristik Ragam Bahasa... 